\title{
Prognostic Value of Combined Detection of Serum and Pleural Fluid Tumor Markers in Non-small Cell Lung Cancer With Malignant Pleural Effusion
}

\section{Li-Xu Xie}

Shi-Chang Jiang

Zi Chen

Shu-Juan Jiang

Xing-Guang Wang ( $\nabla$ xingguang-wang@163.com )

Lin-Fu Zhou

\section{Research}

Keywords: Tumor markers, Malignant pleural effusion, Non-small cell lung cancer, Prognosis

Posted Date: June 17th, 2020

DOI: https://doi.org/10.21203/rs.3.rs-35527/v1

License: (c) (i) This work is licensed under a Creative Commons Attribution 4.0 International License. Read Full License 


\section{Abstract}

Background: Serum tumor markers are considered a negative prognostic factor in non-small cell lung cancer (NSCLC). Combined detection of serum and pleural fluid (PF) tumor markers is rarely reported. The aim of this study was to analyze the relationship between combined detection of serum and pleural fluid (SPF) tumor markers and prognosis in advanced NSCLC.

Results: High levels of SPF CEA $(P=0.001)$, SPF CYFRA21-1 $(P=0.001)$ and SPF CA-125 $(P=0.023)$ were adversely prognostic factors for overall survival (OS). High levels of SPF CEA $(P=0.003)$, SPF CYFRA21-1 $(P=0.001)$ and SPF NSE $(P=0.019)$ were related to worse progression-free survival (PFS). In multivariate analysis high levels of SPF CYFRA21-1 was a independent predictor of OS and high levels of SPF CEA and SPF CYFRA21-1 were independent predictors of PFS.

Conclusions: High levels of SPF CEA and SPF CYFRA21-1 are correlated with worse survival in advanced NSCLC patients with MPE. The identification of prognostic factors maybe useful in stratifying high-risk populations and will assist the choice of treatment planning.

\section{Background}

Non-small cell lung cancer (NSCLC) remains a leading cause of cancer-related death worldwide, representing about $80 \%$ of lung cancer [1,2]. Despite significant advances in public awareness and medical care, more than $50 \%$ of patients diagnosed with NSCLC have distant metastases and only $16 \%$ of cases are diagnosed at eariy stages [3]. Several prognostic factors of patients with NSCLC have been reported; however, many factors require invasive examination or surgery [4]. The measurement of serum or pleural fluid (PF) tumor markers are inexpensive method and routinely available.

For lung cancer diagnosis, the related markers are carcinoembryonic antigen (CEA), soluble fragment of cytokeratin 19 (CYFRA21-1) and neuron-specific enolase (NSE). Recent studies have reported that high levels of CEA, CYFRA21-1, NSE and carbohydrate antigen (CA)-125 are associated with poor prognosis in NSCLC [5-7]. CEA is a glycoprotein in carcinoembryonic cell surface, and it has been a widely applied tumor marker in serum and PF. In NSCLC, CEA has been considered a marker for the adenocarcinoma histological subtype [8]. CYFRA21-1 is a soluble fragment of cytokeratin 19 and a primitively expressed epithelial cytokeratin. CA-125 is a mucinous glycoprotein originated from fetal lumen epithelium and it is used for the follow-up of ovarian cancer [9]. NSE is an isozyme of enolase, existed in neuroendocrine tumors. NSE is a sensitive marker in the diagnosis of small cell lung cancer (SCLC), but increased serum NSE has been reported in $11.7 \%$ to $28 \%$ of patients with NSCLC [5].

However, the findings regarding the prognosis of serum tumor markers have been studied in lung cancer with conflicting results and the relationship between combined detection of serum and PF tumor markers and prognosis in advanced NSCLC is unclear [10-12]. Therefore, the aim of this study is to assess the prognostic value of combined detection of serum and PF tumor markers CEA, CYFRA21-1, CA-125 and NSE in advanced NSCLC. 


\section{Methods}

\section{Patients}

Two hundred and forty four patients diagnosed with NSCLC by thoracoscopy for malignant pleural effusion (MPE) between 2005 and 2017 at a tertiary hospital were retrospectively reviewed. Inclusion criteria was as follows: (i). Inpatients who voluntarily signed informed consent for specimen collection histologically comfirmed NSCLC. (ii). Survival status could be determined. The duration of OS was studies from the date of diagnosis to the date of death. Progression-free survival (PFS) was calculated from lung cancer diagnosis to first event (progression or death from any reason). (iii) All clinical data were available. (iv) Patients underwent active anticancer treatment. Docetaxel, gemcitabine, pemetrexed or paclitaxel combined with carboplatin/cisplatin as systemic conventional chemotherapy regimens for NSCLC. Patients with positive epidermal growth factor recepor (EGFR) mutations were treated with gefitinib, erlotinib or afatinib. Patients with positive anaplastic lymphoma kinase (ALK) translocations were treated with crizotinib. Exclusion criteria: (i). Patients with heart, kidney, liver and other disease were at high risk of chemotherapy. (ii). The clinical data were incomplete. (iii). Patients did not receive anticancer treatment. The local ethics committee approved this study.

\section{Sample collection and detection}

As part of the routine tests for suspicion of lung cancer, tumor markers were acquired initially at the first visit to the hospital. CEA, CYFRA21-1, CA-125 and NSE were collected in all populations.

PF samples were obtained via thoracocentesis before thoracoscopy and were collected in dry tubes. Venous blood sample were acquired from patients. The samples were centrifuged for 10 min at $1500 \mathrm{~g}$, and stored at $-20^{\circ} \mathrm{C}$ until assayed. The levels of tumor markers were measured with electrochemiluminescence in both PF and serum. The optimal cutoff values of tumor markers were used the cut-off value of hospital routine use. The upper limit of the normal values were at $10.0 \mathrm{ng} / \mathrm{ml}$ for CEA, $6.0 \mathrm{ng} / \mathrm{ml}$ for CYFRA21-1, $39.0 \mathrm{U} / \mathrm{ml}$ for CA-125 and $16.3 \mathrm{ng} / \mathrm{ml}$ for NSE, respectively.

\section{Data collection}

Clinicopathological data including age, sex, histology (adenocarcinoma and squamous carcinoma), smoking status and first line treatment programme were assessed for all enrolled patients. From laboratory data, serum tumor markers CEA, CYFRA21-1, CA-125 and NSE and pleural fluid tumor markers CEA, CYFRA21-1, CA-125 and NSE were evaluated.

\section{Statistical analysis}

Statistical analysis were performed using statistical software (SPSS version 17.0, Chicago, IL). Continuous variables were presented as means \pm standard deviations or medians. The levels of tumor markers in serum and PF were compared using t-tests. The Kaplan-Meier univariate analysis was employed to determine the significance of variables for OS and PFS. The Cox proportional hazard regression model 
was performed for multivariate survival analysis. Log-rank test and Kaplan-Meier analysis were used to determine survival differences. For all analyses, statistical significance was accepted for $P$ values less than 0.05 .

\section{Results}

\section{Baseline characteristics of patients}

A total of 335 patients with MPE were histologically comfirmed NSCLC. Ninety-one patients were excluded for some reasons, including 45 patients incomplete data, 18 patients lost to follow-up and 28 patient no treatment. Finally, 244 patients were enrolled in this study (Fig 1).

Characteristics of the patients are outlined in Table 1. Their median age was 60 years (31-79 years). Among all patients, 132 (54.1\%) were females and 201 (82.4\%) were diagnosed with adenocarcinoma. For first line anticancer treatment, 194 (79.5\%) patients received traditional systemic chemotherapy and 50 $(20.5 \%)$ patients underwent targeted therapy. Median PFS and OS were 6.1 months and 12.7 months, respectively (Fig 2). Univariate analyses for OS and PFS are shown in Table 1.

Serum CEA was elevated in 155 of the 244 patients analyzed (63.5\%), serum CYFRA21-1 in 137 of 244 patients (56.1\%), serum CA- 125 in 145 of 244 patients(59.4\%), and serum NSE in 135 of 244 patients (55.3\%). PF CEA was elevated in 176 of the 244 patients analyzed (72.1\%), PF CYFRA21-1 in 175 of 244 patients (71.7\%), PF CA-125 in 177 of 244 patients (72.5\%), and PF NSE in 138 of 244 patients $(55.3 \%)$. Serum and pleural fluid (SPF) CEA was elevated in 138 of the 244 patients analyzed (56.6\%), SPF CYFRA21- 1 in 135 of 244 patients (55.3\%), SPF CA-125 in 134 of 244 patients (54.9\%), and SPF NSE in 114 of 244 patients $(46.7 \%)$.

In our population, 44 patients (18.0\%) presented the 4 serum tumor markers elevated, 62 patients $(25.4 \%) 3$ serum tumor markers elevated, 88 patients (36.1\%) 2 serum tumor markers elevated and 35 patients $(14.3 \%) 1$ serum tumor markers elevated.

\section{Levels of tumor markers in serum and PF}

Table 3 describes the levels of serum and PF tumor markers. Serum levels of CEA, CYFRA21-1, CA-125 and NSE were $79.15 \pm 186.36 \mathrm{ng} / \mathrm{mL}, 9.63 \pm 29.36 \mathrm{ng} / \mathrm{mL}, 156.98 \pm 251.65 \mathrm{U} / \mathrm{mL}$ and $19.71 \pm 34.99 \mathrm{ng} / \mathrm{mL}$, respectively. PF levels of CEA, CYFRA21-1, CA-125 and NSE were $280.96 \pm 358.16 \mathrm{ng} / \mathrm{mL}, 136.85 \pm 175.19$ $\mathrm{ng} / \mathrm{mL}, 1103.26 \pm 1340.92 \mathrm{U} / \mathrm{mL}$ and $38.15 \pm 75.10 \mathrm{ng} / \mathrm{mL}$, respectively, and were significantly higher than those in serum (all $P<0.001$ ).

\section{CEA analysis}

High levels of serum CEA was adversely prognostic factors for PFS and OS. The PFS was 6.6 months versus 5.0 months in patients with normal and elevated level of serum CEA $(P=0.003)$ and the OS was 15.0 months versus 12.0 months in patients with normal and high levels of tumor marker $(P=0.030)$. We 
analyzed the prognostic value of combination of serum and pleural fluid CEA. High levels of SPF CEA were related to worse PFS and OS. The PFS was 6.6 months versus 5.0 months in patients with normal and elevated level of SPF CEA $(P=0.003)$ and the OS was 15.3 months versus 10.6 months in patients with normal and high levels of tumor marker $(P=0.001)$ (Fig 3 ).

\section{CYFRA21-1 analysis}

We found that abnormal levels of serum CYFRA21-1 and SPF CYFRA21-1 were negative prognostic factors. The PFS was 6.5 months versus 5.3 months in patients with normal and elevated level of serum CYFRA21-1 $(P<0.001)$ and the OS was 16.1 months versus 11.7 months in patients with normal and high levels of tumor marker $(P=0.004)$. The PFS was 6.5 months versus 5.3 months in patients with normal and elevated level of SPF CYFRA21-1 $(P=0.001)$ and the OS was 15.8 months versus 11.1 months in patients with normal and high levels of tumor marker $(P=0.001)$ (Fig 4$)$.

\section{CA-125 analysis}

Serum CA-125 and SPF CA-125 were negative prognostic factors for OS. The OS was 15.0 months versus 12.0 months in patients with normal and elevated level of serum CA-125 $(P=0.043)$ and 12.7 months versus 12.0 months in patients with normal and high levels of SPF CA-125 $(P=0.023)$ (Fig 5).

\section{NSE analysis}

High levels of SPF NSE was a negative prognostic factor for PFS. The PFS was 6.4 months versus 5.5 months in patients with normal and elevated level of SPF NSE $(P=0.019)($ Fig 6).

\section{Serum CEA, CYFRA21-1, CA-125 and NSEcombination}

We analyzed the prognostic value of combination of serum tumor markers. For patients with 4 tumor markers elevated PFS was 4.0 months versus 5.5 months in patients with 3 tumor markers, 6.4 months in patients with 2 tumor markers, 7.0 months in patients with 1 tumor marker and 6.8 months in patients with all the tumor markers negative $(P=0.001)$. We found the same results for $O S$ in patients with a combination of serum tumor markers $(P=0.018)$ (Fig 7$)$.

Significant variables from univariate analysis were evaluated by multivariate analysis. High levels of SPF CYFRA21-1 (HR 1.581, 95\% Cl 1.138-2.199; $P=0.006$ ) was a independent predictive variable for shorter OS. High levels of SPF CEA (HR 1.426, 95\% $\mathrm{Cl} 1.007-2.018 ; P=0.045)$ and SPF CYFRA21-1 (HR 1.597, 95\% Cl 1.181-2.158; $P=0.002$ ) were independent predictive variables for shorter PFS. Results are shown in Table 2.

\section{Dissusion}

With the progress of molecular biology in recent years, the role of tumor markers in predicting outcome and detecting recurrence of patients with lung cancer has been the subject of extensive researches $[13,14]$. The results of our study indicated that high levels of SPF CEA and SPF CYFRA21-1 may be used as biomarkers 
to predict outcomes in NSCLC with MPE; this conclusion was based on the significant differences in OS and PFS observed in these patients. To the best of our knowledge, this study is the first to analyze the relationship between combined detection of SPF tumor markers and prognosis in advanced NSCLC.

Tumor marker CEA and CYFRA21-1 has been reported as poor prognostic factors in NSCLC. In patients with stage IIIB-IV NSCLC, Arrieta et al. showed that patients with elevated serum CEA had shorter OS than patients who had normal levels [15]. In patients with stage I-III NSCLC, Tomita et al. observed that elevated CEA in pleural lavage fluid (PLF) was a significant prognostic factor for OS [16]. In the meta-analysis of Zhang et al. with 1990 patients, serum CYFRA21-1 and CEA were independent prognosis factors of NSCLC patients [6]. We found that high levels of serum CEA and CYFRA21-1 were unfavorable prognostic factors for survival, but this results were inconsistent with Tokito et al[13]. Interestingly, when combining use of serum and pleural fluid tumor markers, we found that SPF CEA and CYFRA21-1 correlated with prognosis in a significant and independent manner. In other words, high levels of SPF CEA and CYFRA21-1 may be useful noninvasiveness markers to identify advanced NSCLC risk. It is not surprising that the relationship between elevated CEA or CYFRA21-1 levels and prognosis remains controversial. In fact, many studies reporting on the prognosis of tumor markers levels were based on different stages or subtypes. Further prospective validation of our data would be necessary.

Previously, Muley et al. introduced the use of a Tumor Marker Index (TMI), based on the combined use of serum CEA and CYFRA21-1 [17]. Muley et al. showed that TMI was the prognostic significance in operate early stage of NSCLC, and this is substantiated by Tomita et al [18]. Barlèsi et al. analyzed the prognotic value of combination of CEA, CYFRA21-1 and NSE in stage IIIB-IV NSCLC and found that combination of the three markers was a poor prognostic factor [19]. In contrast, Blankenburg et al. reported that TMI was not associated with a worse outcome in stage I NSCLC [20]. In the present study, the use of tumor marker indexs including serum CEA, CYFRA21-1, CA-125 and NSE evaluated the prognosis and progression of patients with stage IV NSCLC. We found that combining of the four markers was a poor prognostic factor. The simultaneous use of several serum tumor markers may increase the reliability of prognostic value.

Several reports have been published about the prognostic value of serum CA-125 and NSE. In a random survival forest prognostic model, serum CA-125 was related to a poor outcome in lung adenocarcinoma patients with brain metastasis [21]. Li et al. reported that high levels of serum NSE was correlated with worse survival in resected lung adenocarcinoma patients harboring anaplastic lymphoma kinase (ALK) fusion gene rearrangements [7]. We found that serum CA-125 and SPF CA-125 were prognostic risk factors for OS. In our study, serum NSE was not a prognostic factor, but SPF NSE was associated with worse PFS.

We aslo found that PF levels of CEA, CYFRA21-1, CA-125 and NSE were significantly higher than those in serum. Because of the large molecular weight of tumor markers, they are easier to accumulate in the pleural cavity than the blood. Also, tumor markers in the pleural cavity are not easily inactivated by liver. Hackner et al. showed that ratio of CEA in PF and serum was a useful tool for diagnosis of MPE [22].

There are several limitations in our retrospective study. The populations enrolled in the study were suitable for undergoing thoracoscopy and the selection bias could not be completely avoided. In addition, we did 
not perform the trials evaluating the use of consecutive measurenment of tumor markers during treatment and follow-up. Finally, further prospective study in this area are warranted.

\section{Conclusions}

In conclusion, high levels of tumor markers at baseline are correlated with worse survival in advanced NSCLC patients with MPE. The identification of prognostic factors maybe useful in stratifying high-risk populations and will assist the choice of treatment planning.

\section{Availability of data and materials}

\section{Abbreviations}

NSCLC: non-small cell lung cancer

PF: pleural fluid

SPF: serum and pleural fluid

OS: overall survival

PFS: progression-free survival

CEA: carcinoembryonic antigen

CYFRA21-1: soluble fragment of cytokeratin 19

NSE: neuron-specific enolase

MPE: malignant pleural effusion

EGFR: epidermal growth factor recepor

ALK: anaplastic lymphoma kinase

\section{Declarations}

Acknowledgements: The authors alone are responsible for the content and writing of the paper.

Funding: This work was supported by grants from the National Key Research and Development Program of China 2018YFC1313602, Major International (Regional) Joint Research Project 81820108001, National Natural Science Foundation of China 81670029, Jiangsu Key Principal Investigator of Medicine ZDRCA 2016018, and Project 333 for Cultivation of Young and Middle-aged Leading Talents BRA2019078 (to L.F. Zhou). 
Contributions: Li-Xu Xie conceived and designed this study and wrote the manuscript. Shi-Chang Jiang and Zi Chen participated in data collection and analysis. Shu-Juan Jiang, Xing-Guang Wang and Lin-Fu Zhou critically guided the revision of the manuscript. All authors read the manuscript and approved it for publication.

Corresponding authors: Correspondence to Lin-Fu Zhou or Xing-Guang Wang

Conflict of interest: The authors report no conflicts of interest.

Ethical approval: This study was approved by the Ethics Committee of the Shandong Provincial Hospital. All data generated by this study are included in the manuscript.

\section{References}

1. Siegel RL, Miller KD, Jemal A. Cancer statistics, 2018. CA Cancer J Clin. 2018; 68(1): 7-30.

2. Zhang $H$, Zhang $L$, Zhu K, et al. Prognostic significance of combination of preoperative platelet count and neutrophil-lymphocyte ratio (COP-NLR) in patients with non-small cell lung cancer: based on a large cohort study. PloS one. 2015; 10: e0126496.

3. Miller KD, Siegel RL, Lin CC, et al. Cancer treatment and survivorship statistics, 2016. CA: a cancer journal for clinicians. 2016; 66: 271-289.

4. Xie LX, Wang XG, You WJ, et al. Predictors of Survival in Non-Small Cell Lung Cancer patients with Pleural Effusion Undergoing Thoracoscopy. Thorac Cancer. 2019; 10(6): 1412-1418.

5. Cedrés S, Nuñez I, Longo M, et al. Serum tumor markers CEA, CYFRA21-1, and CA-125 are associated with worse prognosis in advanced non-small-cell lung cancer (NSCLC). Clin Lung Cancer. 2011; 12(3): 172-179.

6. Zhang ZH, Han YW, Liang H, Wang LM. Prognostic value of serum CYFRA21-1 and CEA for non-smallcell lung cancer. Cancer Med. 2015; 4(11): 1633-1638.

7. Li S, Cao L, Wang X, et al. Neuron-specific enolase is an independent prognostic factor in resected lung adenocarcinoma patients with anaplastic lymphoma kinase gene rearrangements. Med Sci Monit. 2019; 25: 675-690.

8. Molina R, Filella X, Augé JM, et al. Tumor markers (CEA, CA-125, CYFRA 21-1, SCC and NSE) in patients with non-small cell lung cancer as an aid in histological diagnosis and prognosis. Comparison with the main clinical and pathological prognostic factors. Tumor Biol. 2003; 24: 209218.

9. Medeiros LR, Rossa DD, da Rosa MI, et al. Accuracy of Ca125 in the diagnosis of ovarian tumors: a quantitative systemic review. Eur J Obstet Gynecol Reprod Biol. 2009; 142: 99-105.

10. Hatzakis KD, Froudarakis ME, Bouros D, et al. Prognostic value of serum tumor markers in patients with lung cancer. 2002; 69(1): 25-29. 
11. Liu C, Huang Q, Ma W, et al. A combination of tumor and molecular markers predicts a poor prognosis in lung adenocarcinoma. Int J Clin Exp Pathol. 2019; 12(5): 1690-1701.

12. Zhang $L$, Liu D, Li L, et al. The important role of circulating CYFRA21-1 in metastasis diagnosis and prognostic value compared with carcinoembryonic antigen and neuron-specific enolase in lung cancer patients. BMC Cancer. 2017; 17(1): 96.

13. Tokito T, Azuma K, Yamada K, et al. Prognostic Value of Serum Tumor Markers in Patients With Stage III NSCLC Treated With Chemoradiotherapy. In Vivo. 2019; 33(3): 889-895.

14. Muley $T, \mathrm{He} Y$, Rolny V, et al. Potential for the blood-based biomarkers cytokeratin 19 fragment (CYFRA 21-1) and human epididymal protein 4 (HE4) to detect recurrence during monitoring after surgical resection of adenocarcinoma of the lung. Lung Cancer. 2019; 130: 194-200.

15. Arrieta $\mathrm{O}$, Saavedra-Perez D, Kuri R, et al. Brain metastasis development and poor survival associated with carcinoembryonic antigen (CEA) level in advanced non-small cell lung cancer: a prospective analysis. BMC Cancer. 2009; 9: 119.

16. Tomita M, Shimizu T, Matsuzaki Y, et al. Prognostic significance carcinoembryonic antigen level in pleural lavage fluid for patients with lung adenocarcinoma. Ann Thorac Surg. 2005; 80(1): 276-281.

17. Muley T, Fetz TH, Dienemann H, et al. Tumor volume and tumor marker index based on CYFRA 21-1 and CEA are strong prognostic factors in operated early stage NSCLC. Lung Cancer. 2008; 60(3): 408415.

18. Tomita M, Shimizu T, ayabe T, Yonei A, Onitsuka T. Prognostic significance of tumour marker index based on preoperative CEA and CYFRA21-1 in NSCLC. Anticancer Res. 2010; 30: 3099-3102.

19. Barlèsi F, Gimenez C, Torre JP, et al. Prognostic value of combination of CYFRA 21-1, CEA and NSE in patients with advanced non-small cell lung cancer. Respiratory Med. 2004; 98: 357-362.

20. Blankenburg F, Hatz R, Nagel D, et al. Preoperative CYFRA21-1 and CEA as prognostic factors in patients with stage I NSCLC. Tumor Biol. 2008; 29: 272-277.

21. Wang $H$, Shen $L$, Geng J, et al. Prognostic value of cancer antigen - 125 for lung adenocarcinoma patients with brain metastasis: A random survival forest prognostic model. Sci Rep. 2018; 8(1): 5670.

22. Hackner $K$, Errhalt $P$, Handzhiev $S$. Ratio of carcinoembryonic antigen in pleural fluid and serum for the diagnosis of malignant pleural effusion. Ther Adv Med Oncol. 2019;11:1758835919850341.

\section{Tables}


Table 1. Univariate analysis on OS and PFS in NSCLC

\begin{tabular}{|c|c|c|c|c|c|c|c|c|}
\hline & & & Median & $95 \% \mathrm{Cl}$ & Median & $\begin{array}{l}95 \% \\
\mathrm{Cl}\end{array}$ & & \\
\hline Variables & Value & $\mathrm{n}(\%)$ & $\begin{array}{l}\text { OS } \\
\text { (months) }\end{array}$ & OS & $\begin{array}{l}\text { PFS } \\
\text { (months) }\end{array}$ & PFS & $\mathrm{p}^{\mathrm{a}}$ & $\mathrm{p}^{\mathrm{b}}$ \\
\hline \multirow[t]{3}{*}{ NSCLC } & & 244 & 12.7 & $\begin{array}{l}10.56- \\
14.84\end{array}$ & 6.1 & $\begin{array}{l}5.73- \\
6.87\end{array}$ & 0.146 & 0.294 \\
\hline & Adenocarcinoma & 201 & 15.0 & $\begin{array}{l}12.61- \\
17.39\end{array}$ & 5.6 & $\begin{array}{l}4.94- \\
6.26\end{array}$ & & \\
\hline & Squamous & 43 & 11.8 & $\begin{array}{l}9.24- \\
14.36\end{array}$ & 6.8 & $\begin{array}{l}5.00- \\
8.60\end{array}$ & & \\
\hline \multirow[t]{3}{*}{ Sex } & & & & & & & 0.069 & 0.739 \\
\hline & Male & 112 & 11.7 & $\begin{array}{l}9.54- \\
13.86\end{array}$ & 5.6 & $\begin{array}{l}4.72- \\
6.48\end{array}$ & & \\
\hline & Female & 132 & 14.5 & $\begin{array}{l}11.99- \\
17.00\end{array}$ & 6.4 & $\begin{array}{l}5.46- \\
7.14\end{array}$ & & \\
\hline \multirow[t]{3}{*}{$\begin{array}{l}\text { Age, } \\
\text { Median }\end{array}$} & & & & & & & 0.751 & 0.712 \\
\hline & $\$ 60$ & 114 & 11.1 & $\begin{array}{l}7.59- \\
14.61\end{array}$ & 5.6 & $\begin{array}{l}4.79- \\
6.41\end{array}$ & & \\
\hline & $\geq 60$ & 130 & 14.2 & $\begin{array}{l}12.07- \\
16.33\end{array}$ & 6.3 & $\begin{array}{l}5.64- \\
6.96\end{array}$ & & \\
\hline \multirow[t]{3}{*}{ Smoking } & & & & & & & 0.196 & 0.309 \\
\hline & No & 136 & 14.5 & $\begin{array}{l}12.09- \\
16.91\end{array}$ & 5.5 & $\begin{array}{l}4.78- \\
6.22\end{array}$ & & \\
\hline & Yes & 108 & 11.7 & $\begin{array}{l}8.90- \\
14.50\end{array}$ & 6.5 & $\begin{array}{l}6.14- \\
6.86\end{array}$ & & \\
\hline \multirow[t]{3}{*}{ Treatment } & & & & & & & 0.136 & 0.261 \\
\hline & Conventional & 194 & 14.2 & $\begin{array}{l}11.65- \\
16.75\end{array}$ & 5.5 & $\begin{array}{l}4.82- \\
6.18\end{array}$ & & \\
\hline & Targeted & 50 & 11.8 & $\begin{array}{l}8.92- \\
14.69\end{array}$ & 6.7 & $\begin{array}{l}5.89- \\
7.51\end{array}$ & & \\
\hline \multirow[t]{3}{*}{$\begin{array}{l}\text { Serum } \\
\text { CEA }\end{array}$} & & & & & & & 0.030 & 0.003 \\
\hline & Normal & 89 & 15.0 & $\begin{array}{l}12.13- \\
17.88\end{array}$ & 6.6 & $\begin{array}{l}6.10- \\
7.10\end{array}$ & & \\
\hline & Elevated & 155 & 12.0 & $\begin{array}{l}8.98- \\
15.02\end{array}$ & 5.0 & $\begin{array}{l}4.49- \\
5.51\end{array}$ & & \\
\hline PF CEA & & & & & & & 0.078 & 0.089 \\
\hline
\end{tabular}




\begin{tabular}{|c|c|c|c|c|c|c|c|c|}
\hline & Normal & 68 & 13.5 & $\begin{array}{l}9.46- \\
17.54\end{array}$ & 6.5 & $\begin{array}{l}5.60- \\
7.40\end{array}$ & & \\
\hline & Elevated & 176 & 12.0 & $\begin{array}{l}8.72- \\
15.29\end{array}$ & 5.5 & $\begin{array}{l}4.79- \\
6.21\end{array}$ & & \\
\hline $\begin{array}{l}\text { Elevated } \\
\text { SPF CEA }\end{array}$ & & & & & & & 0.001 & 0.003 \\
\hline & No & 106 & 15.3 & $\begin{array}{l}12.95- \\
17.65\end{array}$ & 6.6 & $\begin{array}{l}6.18- \\
7.02\end{array}$ & & \\
\hline & Yes & 138 & 10.6 & $\begin{array}{l}7.39- \\
13.81\end{array}$ & 5.0 & $\begin{array}{l}4.51- \\
5.49\end{array}$ & & \\
\hline \multirow{3}{*}{$\begin{array}{l}\text { Serum } \\
\text { CA-125 }\end{array}$} & & & & & & & 0.043 & 0.609 \\
\hline & Normal & 99 & 15.0 & $\begin{array}{l}12.08- \\
17.93\end{array}$ & 6.4 & $\begin{array}{l}5.69- \\
7.11\end{array}$ & & \\
\hline & Elevated & 145 & 12.0 & $\begin{array}{l}8.83- \\
15.17\end{array}$ & 5.5 & $\begin{array}{l}5.76- \\
6.24\end{array}$ & & \\
\hline \multirow{3}{*}{$\begin{array}{l}\text { PF CA- } \\
125\end{array}$} & & & & & & & 0.829 & 0.517 \\
\hline & Normal & 67 & 12.5 & $\begin{array}{l}10.55- \\
14.45\end{array}$ & 6.5 & $\begin{array}{l}4.90- \\
7.90\end{array}$ & & \\
\hline & Elevated & 177 & 13.5 & $\begin{array}{l}10.78- \\
16.22\end{array}$ & 6.1 & $\begin{array}{l}5.43- \\
6.77\end{array}$ & & \\
\hline \multirow{3}{*}{$\begin{array}{l}\text { Elevated } \\
\text { SPF CA- } \\
125\end{array}$} & & & & & & & 0.023 & 0.265 \\
\hline & No & 110 & 12.7 & $\begin{array}{l}10.30- \\
15.10\end{array}$ & 6.4 & $\begin{array}{l}5.59- \\
7.21\end{array}$ & & \\
\hline & Yes & 134 & 12.0 & $\begin{array}{l}8.44- \\
15.57\end{array}$ & 5.5 & $\begin{array}{l}4.76- \\
6.24\end{array}$ & & \\
\hline \multirow{3}{*}{$\begin{array}{l}\text { Serum } \\
\text { CYFRA21- } \\
1\end{array}$} & & & & & & & 0.004 & $<0.001$ \\
\hline & Normal & 107 & 16.1 & $\begin{array}{l}12.60- \\
19.60\end{array}$ & 6.5 & $\begin{array}{l}6.11- \\
6.89\end{array}$ & & \\
\hline & Elevated & 137 & 11.7 & $\begin{array}{l}10.49- \\
12.91\end{array}$ & 5.3 & $\begin{array}{l}4.48- \\
6.12\end{array}$ & & \\
\hline $\begin{array}{l}\text { PF } \\
\text { CYFRA21- } \\
1\end{array}$ & & & & & & & 0.620 & 0.157 \\
\hline & Normal & 69 & 14.5 & $\begin{array}{l}11.65- \\
17.35\end{array}$ & 5.0 & $\begin{array}{l}4.06- \\
5.94\end{array}$ & & \\
\hline
\end{tabular}




\begin{tabular}{|c|c|c|c|c|c|c|c|c|}
\hline & Elevated & 175 & 12.0 & $\begin{array}{l}9.53- \\
14.48\end{array}$ & 6.3 & $\begin{array}{l}5.74- \\
6.86\end{array}$ & & \\
\hline \multirow{3}{*}{$\begin{array}{l}\text { Elevated } \\
\text { SPF } \\
\text { CYFRA21- } \\
1\end{array}$} & & & & & & & 0.001 & 0.001 \\
\hline & No & 109 & 15.8 & $\begin{array}{l}13.12- \\
19.08\end{array}$ & 6.5 & $\begin{array}{l}6.11- \\
6.89\end{array}$ & & \\
\hline & Yes & 135 & 11.1 & $\begin{array}{l}9.90- \\
12.30\end{array}$ & 5.3 & $\begin{array}{l}4.49- \\
6.11\end{array}$ & & \\
\hline \multirow{3}{*}{$\begin{array}{l}\text { Serum } \\
\text { NSE }\end{array}$} & & & & & & & 0.445 & 0.075 \\
\hline & Normal & 109 & 12.7 & $\begin{array}{l}10.82- \\
14.58\end{array}$ & 6.4 & $\begin{array}{l}5.53- \\
7.27\end{array}$ & & \\
\hline & Elevated & 135 & 13.5 & $\begin{array}{l}10.21- \\
16.79\end{array}$ & 5.5 & $\begin{array}{l}4.48- \\
6.52\end{array}$ & & \\
\hline \multirow[t]{3}{*}{ PF NSE } & & & & & & & 0.312 & 0.129 \\
\hline & Normal & 106 & 12.5 & $\begin{array}{l}9.22- \\
15.78\end{array}$ & 6.3 & $\begin{array}{l}5.33- \\
7.27\end{array}$ & & \\
\hline & Elevated & 138 & 13.5 & $\begin{array}{l}10.74- \\
16.26\end{array}$ & 5.6 & $\begin{array}{l}4.45- \\
6.75\end{array}$ & & \\
\hline \multirow[t]{3}{*}{$\begin{array}{l}\text { Elevated } \\
\text { SPF NSE }\end{array}$} & & & & & & & 0.235 & 0.019 \\
\hline & No & 130 & 12.7 & $\begin{array}{l}10.65- \\
14.75\end{array}$ & 6.4 & $\begin{array}{l}5.52- \\
7.28\end{array}$ & & \\
\hline & Yes & 114 & 15.0 & $\begin{array}{l}11.97- \\
18.03\end{array}$ & 5.5 & $\begin{array}{l}4.51- \\
6.42\end{array}$ & & \\
\hline \multirow{5}{*}{$\begin{array}{l}\text { Number } \\
\text { of } \\
\text { Elevated } \\
\text { Serum } \\
\text { Tumor } \\
\text { Markers }\end{array}$} & & & & & & & 0.018 & 0.001 \\
\hline & 0 & 15 & 12.7 & $\begin{array}{l}11.58- \\
13.82\end{array}$ & 6.8 & $\begin{array}{l}3.64- \\
9.96\end{array}$ & & \\
\hline & 1 & 35 & 16.1 & $\begin{array}{l}14.75- \\
17.45\end{array}$ & 7.0 & $\begin{array}{l}5.84- \\
8.16\end{array}$ & & \\
\hline & 2 & 88 & 14.5 & $\begin{array}{l}11.47- \\
17.53\end{array}$ & 6.4 & $\begin{array}{l}5.64- \\
7.16\end{array}$ & & \\
\hline & 3 & 62 & 11.8 & $\begin{array}{l}9.48- \\
14.12\end{array}$ & 5.5 & $\begin{array}{l}4.12- \\
6.88\end{array}$ & & \\
\hline
\end{tabular}


a The value of overall survival.

${ }^{b}$ The value of progression-free survival.

OS, overall survival; PFS, progression-free survival; NSCLC, non-small cell lung cancer; $\mathrm{Cl}$, confidence interval; PF, pleural fluid; SPF, serum and pleural fluid.

Table 2. Multivatiate analysis on OS and PFS in NSCLC

\begin{tabular}{|c|c|c|c|c|c|}
\hline \multirow[t]{2}{*}{ Predictors } & $\mathrm{HR}$ & $95 \% \mathrm{Cl}$ & $H R$ & $95 \% \mathrm{Cl}$ & $\mathrm{p}^{\mathrm{b}}$ \\
\hline & OS & OS & PFS & PFS & \\
\hline SPF CEA & 1.399 & $\begin{array}{l}0.988- \\
1.980\end{array}$ & $\begin{array}{l}1.426 \\
0.045\end{array}$ & $1.007-2.018$ & 0.058 \\
\hline SPF CYFRA21-1 & 1.581 & $\begin{array}{l}1.138- \\
2.199\end{array}$ & $\begin{array}{l}1.597 \\
0.002\end{array}$ & $1.181-2.158$ & 0.006 \\
\hline SPF CA-125 & 1.233 & $\begin{array}{l}0.868- \\
1.753\end{array}$ & & 0.242 & \\
\hline SPF NSE & & & 0.127 & $0.933-1.752$ & \\
\hline $\begin{array}{l}\text { Number of elevated serum tumor } \\
\text { markers }\end{array}$ & 1.018 & $\begin{array}{l}0.851- \\
1.219\end{array}$ & $\begin{array}{l}1.024 \\
0.810\end{array}$ & $0.844-1.242$ & 0.845 \\
\hline
\end{tabular}

a The value of overall survival.

b The value of progression-free survival.

OS, overall survival; PFS, progression-free survival; NSCLC, non-small cell lung cancer; $\mathrm{HR}$, hazard ratio; $\mathrm{Cl}$, confidence interval; SPF, serum and pleural fluid. 
Table 3. Levels of tumor markers in serum and pleural fluid

\begin{tabular}{|lclll|}
\hline Types & CEA $(\mathrm{ng} / \mathrm{mL})$ & CA-125 $(\mathrm{U} / \mathrm{mL})$ & $\begin{array}{c}\text { CYFRA21-1 } \\
(\mathrm{ng} / \mathrm{mL})\end{array}$ & $\begin{array}{c}\mathrm{NSE} \\
(\mathrm{ng} / \mathrm{mL})\end{array}$ \\
\hline Serum (Mean \pm SD) & $79.15 \pm 186.36$ & $156.98 \pm 251.65$ & $9.63 \pm 29.36$ & $19.71 \pm 34.99$ \\
\hline $\begin{array}{l}\text { Pleural fluid (Mean } \pm \\
\text { SD) }\end{array}$ & $280.96 \pm 358.16 \square$ & $1103.26 \pm 1340.92 \square$ & $136.85 \pm 175.19 \square$ & $38.15 \pm 75.10 \square$ \\
\hline
\end{tabular}

$\square p<0.001, v s$ serum tumor markers.

Figures

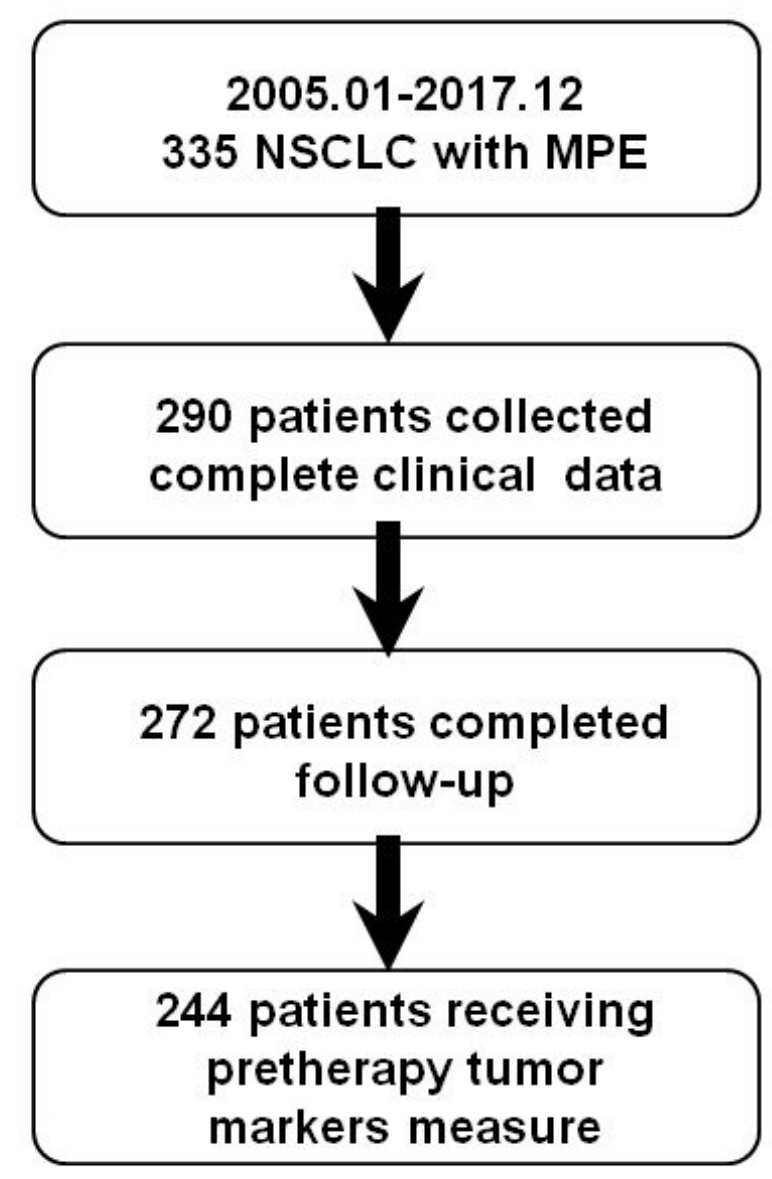

Figure 1

Flowchart of patient numbers 
(a)

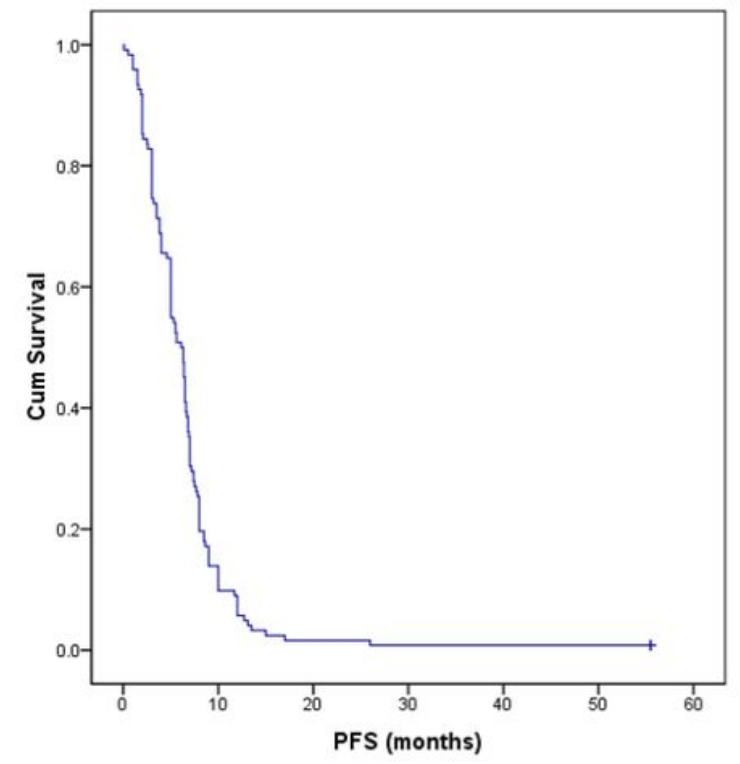

(b)<smiles>CC(C)(C)C1CCCC1</smiles>

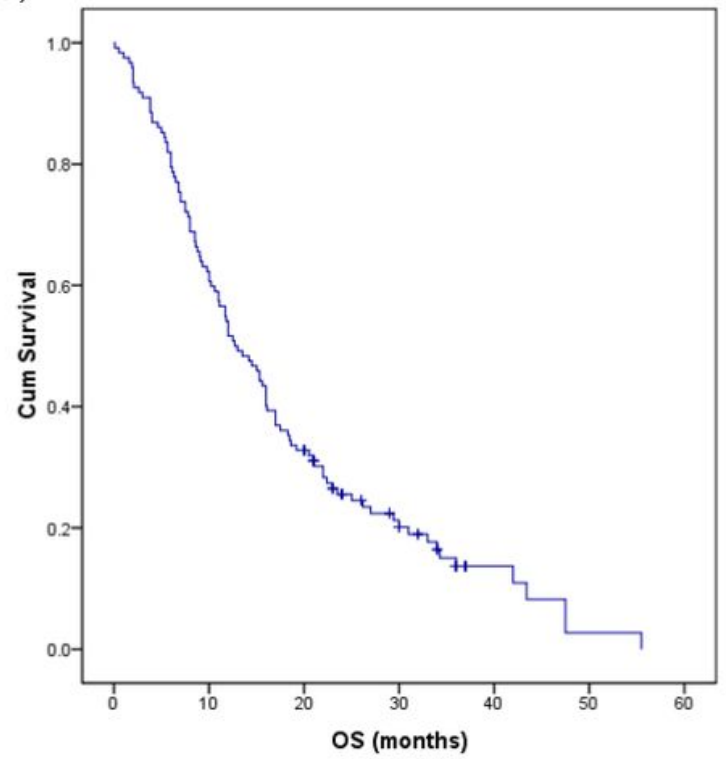

\section{Figure 2}

Kaplan-Meier curve demonstrating the survival of the non-small cell lung cancer patients. (a) The median survival for progression-free survival (PFS) was 6.1 months. (b) The median survival for overall survival (OS) was 12.7 months 
(a)

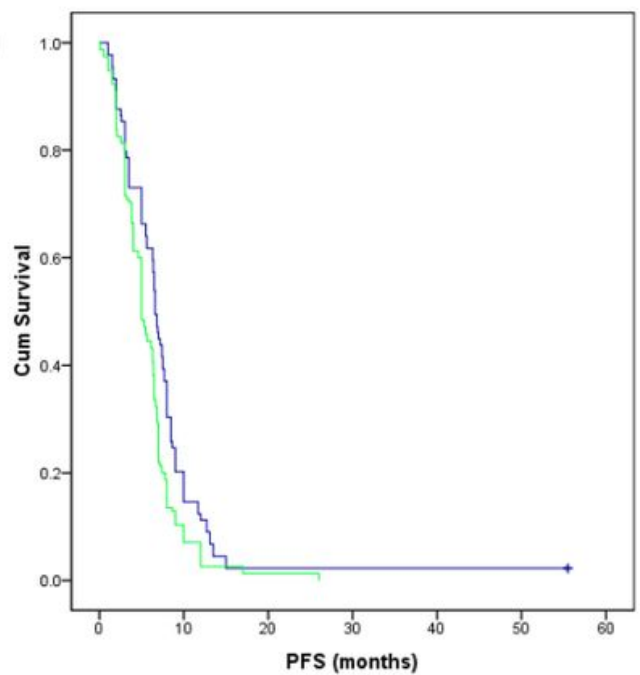

(c)

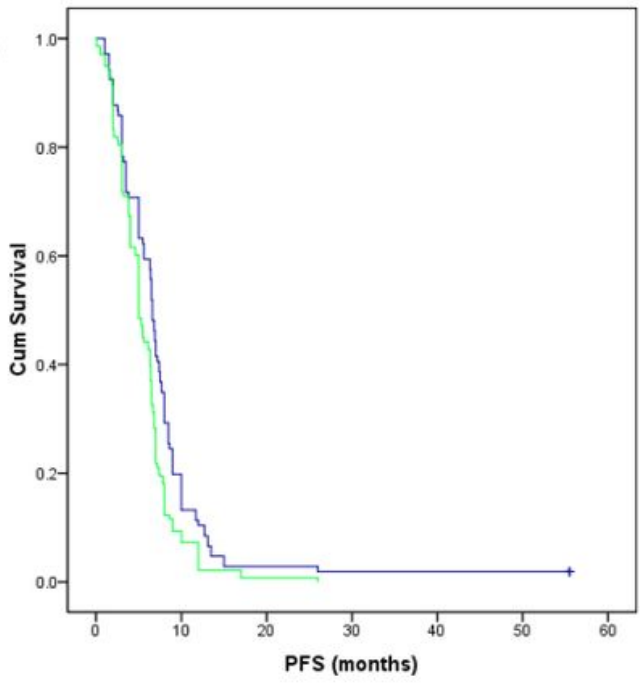

Serum CEA $\rightarrow<10.0 \mathrm{ng} / \mathrm{mL}$ $7 \geqslant 10.0 \mathrm{ng} / \mathrm{ht}$
+ censord

+ censord

Elevated SPF CEA

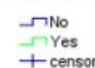

+ censord

censor (b)

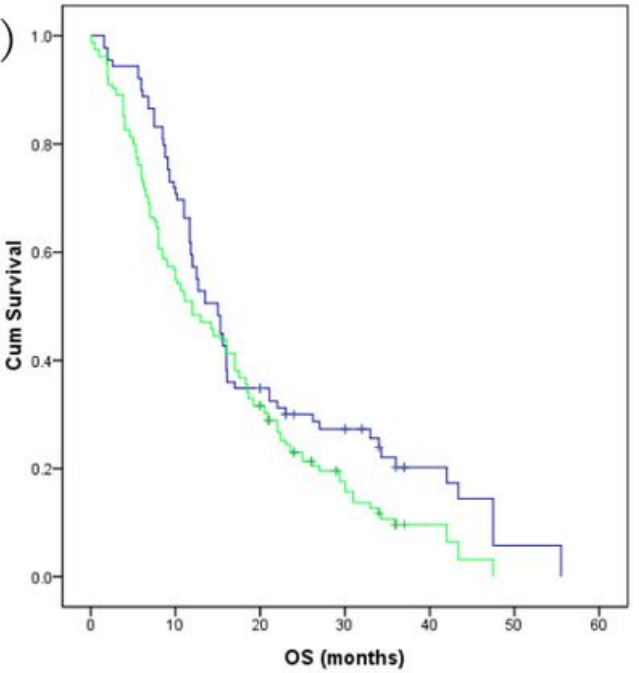

(d)

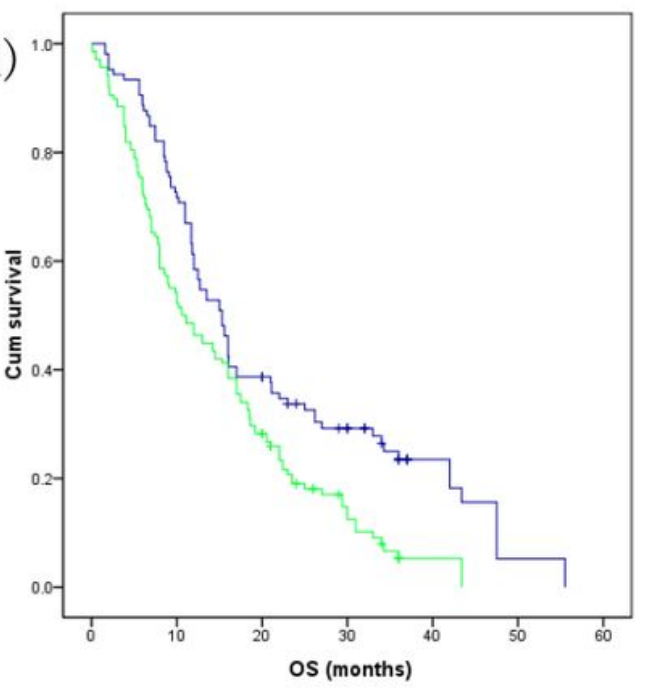

Serum CEA

$\pi<10.0 \mathrm{ng} / \mathrm{mL}$

+ censord

Ievated SPF CEA InNo
ITYes + Yes

F censord

\section{Figure 3}

Kaplan-Meier curves demonstrating the relationship of CEA with survival in non-small cell lung cancer patients. (a) Progression-free survival (PFS) probability in patients with elevated vs. normal serum CEA (P $=0.003$ ). (b) Overall survival (OS) probability in patients with elevated vs. normal serum CEA $(P=0.030)$. (c) PFS probability in patients with elevated vs. normal combined detection of serum and pleural fluid (SPF) CEA $(P=0.003)$. (d) OS probability in patients with elevated vs. normal SPF CEA $(P=0.001)$ 
(a)

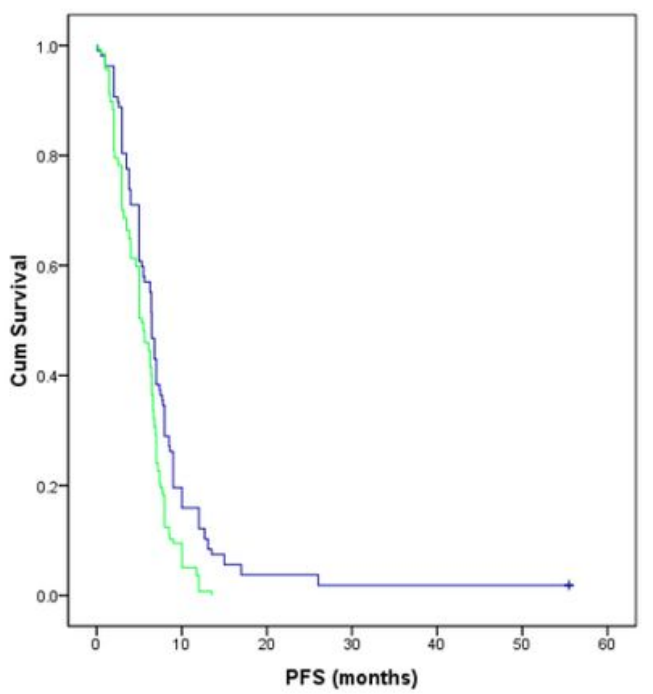

(c)

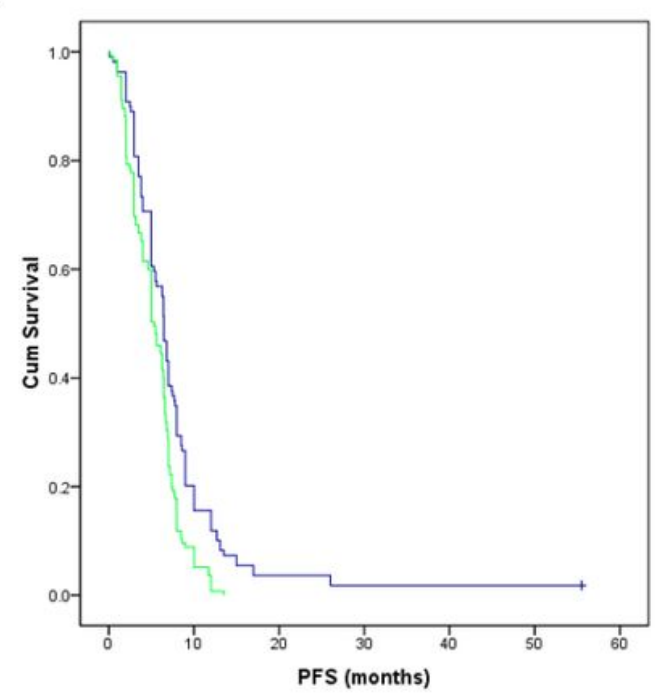

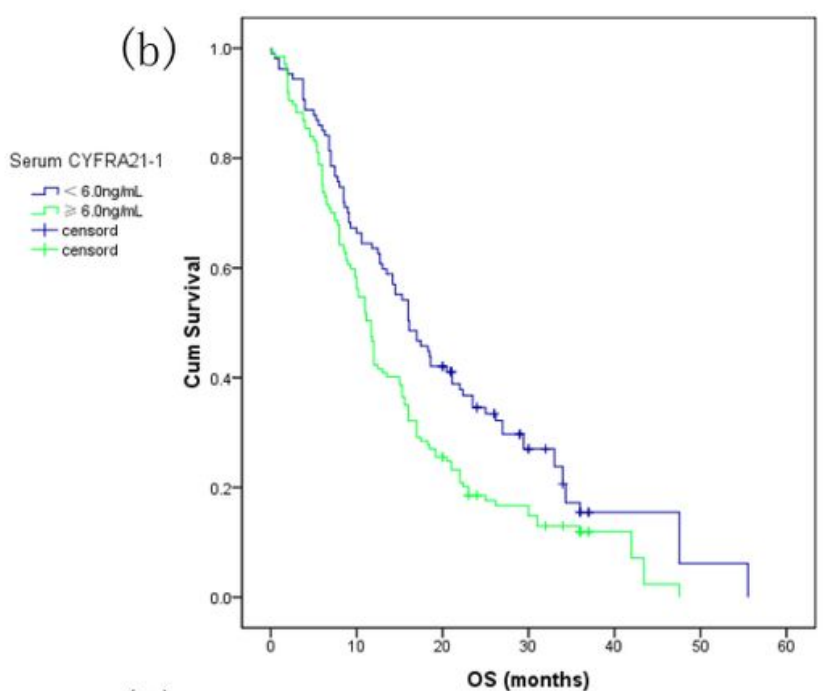

(d)

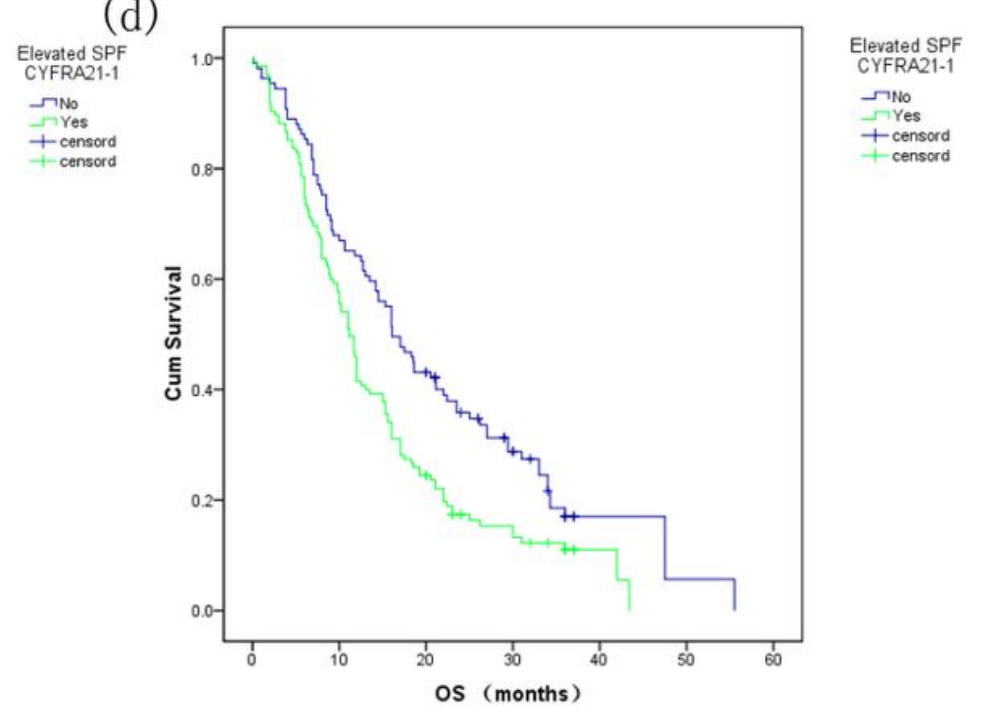

\section{Figure 4}

Kaplan-Meier curves demonstrating the relationship of CYFRA21-1 with survival in non-small cell lung cancer patients. (a) Progression-free survival (PFS) probability in patients with elevated vs. normal serum CYFRA21-1 $(P<0.001)$. (b) Overall survival $(O S)$ probability in patients with elevated vs. normal serum CYFRA21-1 ( $P=0.004)$. (c) PFS probability in patients with elevated vs. normal combined detection of serum and pleural fluid (SPF) CYFRA21-1 $(P=0.001)$. (d) OS probability in patients with elevated vs. normal SPF CYFRA21-1 $(P=0.001)$ 
(a)

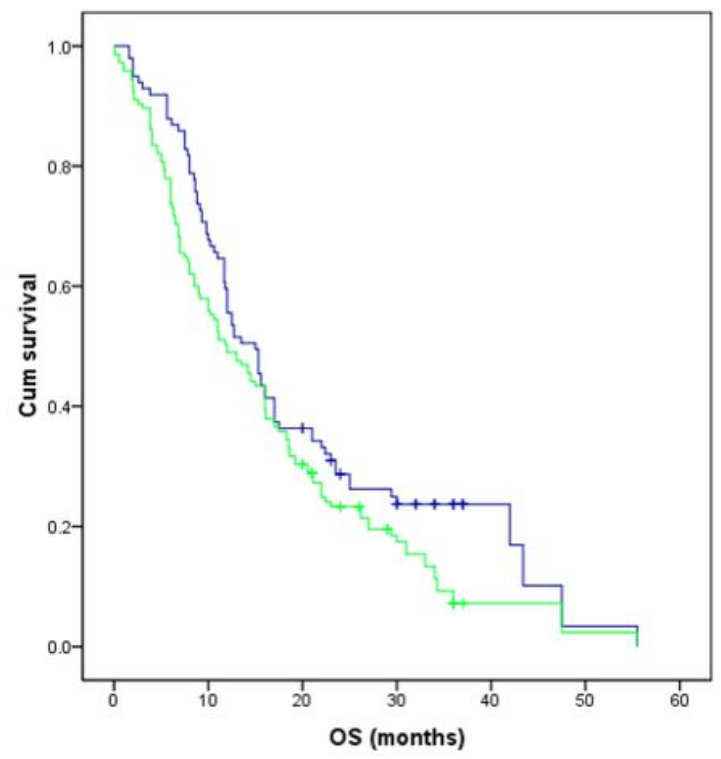

(b)

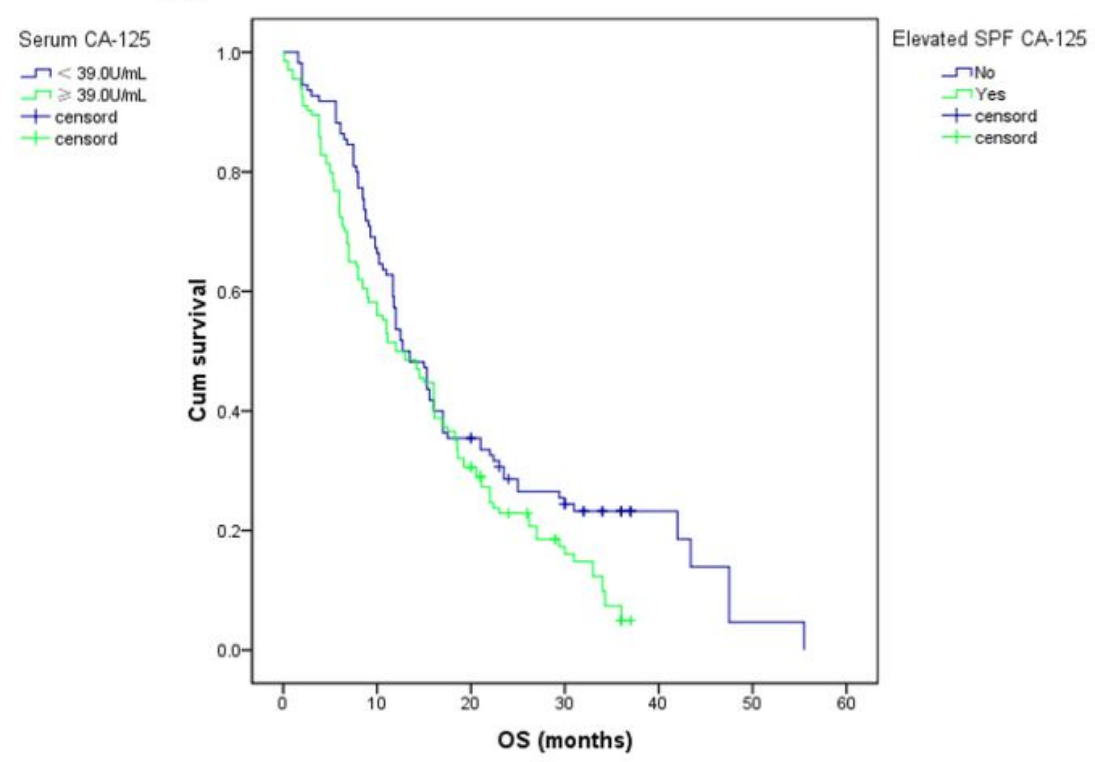

\section{Figure 5}

Kaplan-Meier curves demonstrating the relationship of CA-125 with survival in non-small cell lung cancer patients. (a) overall survival (OS) probability in patients with elevated vs. normal serum CA-125 (P = 0.043). (b) OS probability in patients with elevated vs. normal combined detection of serum and pleural fluid (SPF) CA-125 ( $\mathrm{P}=0.023)$ 


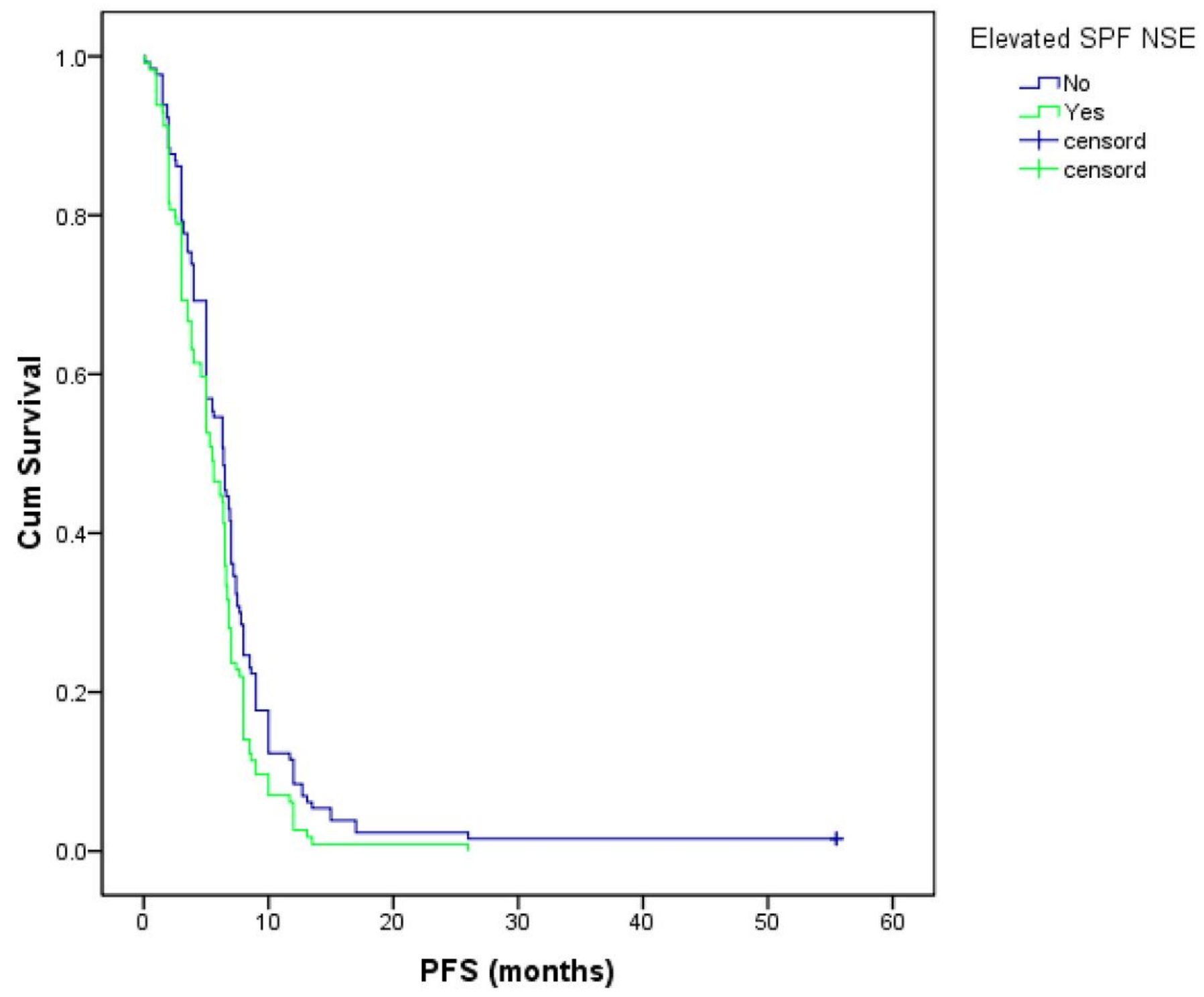

Figure 6

Kaplan-Meier curves demonstrating the relationship of combined detection of serum and pleural fluid (SPF) NSE with progression-free survival (PFS) in non-small cell lung cancer patients $(P=0.019)$ 
(a)

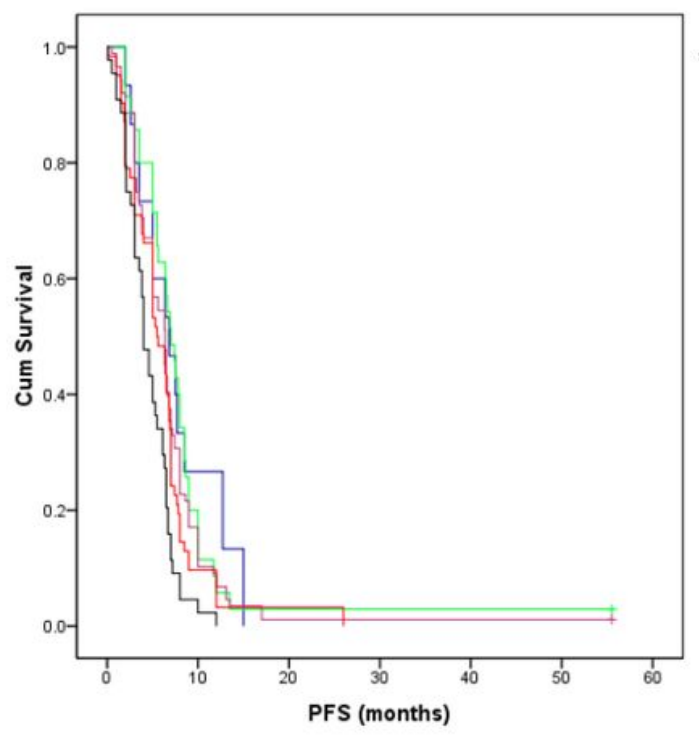

(b)

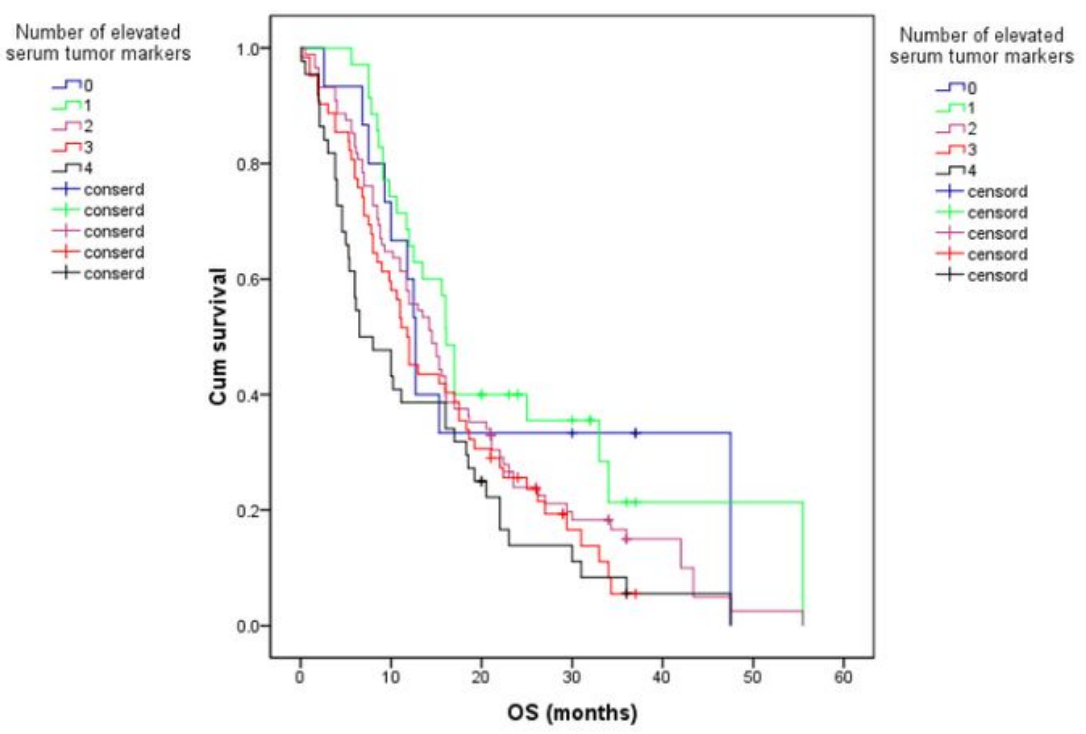

\section{Figure 7}

Kaplan-Meier curves demonstrating the relationship of number of elevated serum tumor markers with progression-free survival (PFS) $(a, P=0.001)$ and overall survival $(O S)(b, P=0.018)$ 